\title{
The Isolation of a Large Cyclopentadienylcobaltsulfide Cluster. The Synthesis and Crystal Structure of Octahedral $\operatorname{clos} o-\left(\eta^{5}-\mathrm{C}_{5} \mathrm{H}_{5} \mathrm{Co}\right)_{5} \mathrm{~S}$
}

\author{
Ryan L. Holland · Joseph M. O’Connor • \\ Arnold L. Rheingold
}

Received: 27 November 2008/Published online: 13 February 2009

(C) The Author(s) 2009. This article is published with open access at Springerlink.com

\begin{abstract}
The title cluster, which was obtained serendipitously when $\left(\eta^{5}-\mathrm{C}_{5} \mathrm{H}_{5}\right)$ $\mathrm{Co}\left(\mathrm{PPh}_{3}\right)_{2}$ was added to a $\left(\eta^{5}-\mathrm{C}_{5} \mathrm{H}_{5}\right)$ Co metallacyclobutene containing a sulfone group, is the largest cluster known, formed primarily with $\left(\eta^{5}-\mathrm{C}_{5} \mathrm{H}_{5}\right)$ Co vertices. The closo- $\left(\eta^{5}-\mathrm{C}_{5} \mathrm{H}_{5} \mathrm{Co}\right)_{5} \mathrm{~S}$ is a closed-shell, octahedral cluster which forms black, monoclinic crystals from methanol.
\end{abstract}

Keywords Cyclopentadienylcobalt-sulfide cluster · Isolobal analogue · Closo-octahedral complex

\section{Introduction}

Transition-metal clusters containing main group elements in their framework are, among other things, of interest as models for metal-S biologically important systems, as precursors to conducting and thermoelectric phases, and for their catalytic activity $[1,2]$. Progress in this field has been characterized by the creative selection of cluster-forming precursors, while letting nature sort out the outcome. Few large clusters have been designed and prepared in the more systematic and rational manner characterizing organic synthesis. Our studies into the reactivity of late-metal metallacyclobutene complexes have now led to the serendipitous isolation of an unusual pentanuclear cobalt chalcogenido cluster, the title compound closo- $\left[\left(\eta^{5}-\mathrm{C}_{5} \mathrm{H}_{5}\right) \mathrm{Co}\right]_{5} \mathrm{~S}(\mathbf{1})$.

R. L. Holland · J. M. O'Connor · A. L. Rheingold ( $ه)$

Department of Chemistry and Biochemistry, University of California,

La Jolla, San Diego, CA 92093-0358, USA

e-mail: arheingold@ucsd.edu 


\section{Experimental}

\section{General Procedures}

All manipulations were performed under an atmosphere of dinitrogen, or in a Vacuum Atmospheres inert atmosphere glove box equipped with a Dri-Train MO 40-1 purifier. Toluene was distilled over sodium/benzophenone ketyl and rigorously degassed prior to use. Complex 2 and $\left(\eta^{5}-\mathrm{C}_{5} \mathrm{H}_{5}\right) \mathrm{Co}\left(\mathrm{PPh}_{3}\right)_{2}$ were prepared by literature methods $[3,4]$.

\section{Preparation of closo- $\left[\left(\eta^{5}-\mathrm{C}_{5} \mathrm{H}_{5}\right) \mathrm{Co}\right]_{5} \mathrm{~S}(\mathbf{1})$}

In the dry box, a $100-\mathrm{mL}$ thick-walled reaction tube equipped with a threaded Telfon plug and $o$-ring, was charged with the metallacyclobutene complex, $\left(\eta^{5}\right.$ $\left.\mathrm{C}_{5} \mathrm{H}_{5}\right) \mathrm{Co}\left(\mathrm{PPh}_{3}\right) \mathrm{Co}\left\{\kappa^{2}\left(C^{1}, C^{3}\right)-\mathrm{C}\left(\mathrm{SO}_{2} \mathrm{Ph}\right)=\mathrm{C}(\mathrm{TMS}) \mathrm{C}(\mathrm{H})\left(\mathrm{CO}_{2} \mathrm{C}_{2} \mathrm{H}_{5}\right)\right\} \quad(2 ; 356.4 \mathrm{mg}$, $0.50 \mathrm{mmol}),\left(\eta^{5}-\mathrm{C}_{5} \mathrm{H}_{5}\right) \mathrm{Co}\left(\mathrm{PPh}_{3}\right)_{2}(524.2 \mathrm{mg}, 0.81 \mathrm{mmol})$, and toluene $(50 \mathrm{~mL})$. The flask was sealed and the solution heated at $100{ }^{\circ} \mathrm{C}$ for $16 \mathrm{~h}$. The reaction mixture was chromatographed on alumina in the dry box using $10 \%$ EtOAc/benzene as eluent. Two distinct brownish bands were observed. The bands were collected, the volatiles removed under vacuum, and the residue dissolved in methanol. Slow evaporation of the methanol from the first of the fractions led to the formation of a small yield $(<1 \%)$ of narrow, blade-like black crystals of $1 .{ }^{1} \mathrm{H}$ NMR spectroscopic analysis of the material that remained in the mother liquor suggested that a dicobalt complex had formed in addition to $\mathbf{1}$. We have to date been unsuccessful in characterizing that product.

\section{Structure Determination}

Crystallographic data for $\mathbf{1}$ are summarized in Table 1. Data were collected using a Bruker D8 platform diffractometer equipped with an APEX CCD detector and a KryoFlex low-temperature apparatus. Crystals of closo- $\left[\left(\eta^{5}-\mathrm{C}_{5} \mathrm{H}_{5}\right) \mathrm{Co}\right]_{5} \mathrm{~S}(\mathbf{1})$ grew as very narrow black blades from $\mathrm{MeOH}$ and were mounted with mineral oil on a Nylon loop. The structure was solved by direct methods and refined by least squares on $F^{2}$. All non-hydrogen atoms were refined anisotropically and all hydrogen atoms were idealized. All software used in the data collection, solution, and refinement is contained in the APEX and SHELXTL libraries maintained by Bruker-AXS (Madison, WI).

\section{Results and Discussion}

Presumably, complex 1 forms from the oligomerization of $\left(\eta^{5}-\mathrm{C}_{5} \mathrm{H}_{5}\right)$ Co moieties and a sulfide ion in solution (Scheme 1). It appears that the sulfur present in $\mathbf{1}$ is derived from the phenyl sulfone in complex $\mathbf{2}$, although the small quantities of $\mathbf{1}$ do not allow us to rule out that traces of sulfur-containing impurities may have been present in the starting material. Mechanistically, the six-electron reduction of the 
Table 1 Data collection and structure refinement details for closo- $\left[\left(\eta^{5}-\mathrm{C}_{5} \mathrm{H}_{5}\right) \mathrm{Co}\right]_{5} \mathrm{~S}(\mathbf{1})$

\begin{tabular}{ll}
\hline Formula & $\mathrm{C}_{25} \mathrm{H}_{25} \mathrm{Co}_{5} \mathrm{~S}$ \\
$F w$ & 652.16 \\
$T(\mathrm{~K})$ & $100(2)$ \\
Radiation source & Mo- $K \alpha 0.71073 \AA$ \\
Cryst system & Monoclinic \\
Space group & $P 2_{1} / c$ \\
Unit cell dimensions & $a=9.3980(12) \AA$ \\
& $b=17.011(2) \AA$ \\
& $c=14.0890(18) \AA$ \\
$V\left(\AA^{3}\right)$ & $\beta=106.064(2)^{\circ}$ \\
$Z$ & $2164.5(5)$ \\
Density (calculated) & 4 \\
Absorption coefficient & $2.001 \mathrm{mg} / \mathrm{m}^{3}$ \\
Crystal size & $3.860 \mathrm{~mm}{ }^{-1}$ \\
Reflections collected, independent & $0.14 \times 0.02 \times 0.01 \mathrm{~mm}^{3}$ \\
Completeness to theta $=25.00^{\circ}$ & 18416,5015 \\
GOF on $F^{2}$ & $99.9 \%$ \\
Final $R$ indices $[I>2$ sigma $(I)]$ & $R 1=0.030$ \\
$R$ indices (all data) & $R 1=0.0604, w R 2=0.0656$ \\
Residual electron density $(\mathrm{max} / \mathrm{min})$ & $0.782 /-0.615$ \\
\hline
\end{tabular}

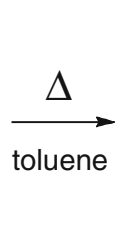

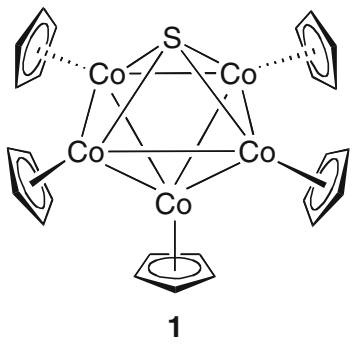

Scheme 1 The synthesis of 1

sulfone to a terminal sulfido presents difficulty, though this transformation may be facilitated by a metal-mediated oxidation of free triphenylphospine to triphenylphosphine oxide and subsequent metal-mediated $\mathrm{C}-\mathrm{S}$ bond cleavages [5-9].

The core atoms of closo- $\left[\left(\eta^{5}-\mathrm{C}_{5} \mathrm{H}_{5}\right) \mathrm{Co}_{5} \mathrm{~S}, \mathbf{1}\right.$, form an octahedral structure (Fig. 1) $[1,2,10]$. Selected bond distances and angles are presented in Table 2. The core structure electron count is 74 , but if the sulfur atom is considered as the isolobal equivalent of a 16-electron transition-metal fragment [2], then the valence electron count is the same as required for a closo structure of all transition-metal atoms obeying the 18-electron rule. With five $\left(\eta^{5}-\mathrm{C}_{5} \mathrm{H}_{5}\right) \mathrm{Co}$ fragments, it is the largest $\left(\eta^{5}-\mathrm{C}_{5} \mathrm{H}_{5}\right)$ Co-based cluster known. There are several clusters containing $\left[\left(\eta^{5}-\mathrm{C}_{5} \mathrm{H}_{5}\right) \mathrm{Co}\right]_{4}$, one being the related disulfide complex, trans- $\left[\left(\eta^{5}-\mathrm{C}_{5} \mathrm{H}_{5}\right) \mathrm{Co}\right]_{4} \mathrm{~S}_{2}$ (3) [11]. As a closo-octahedral cluster, $\mathbf{1}$ is isolobally related to the group- 9 , 


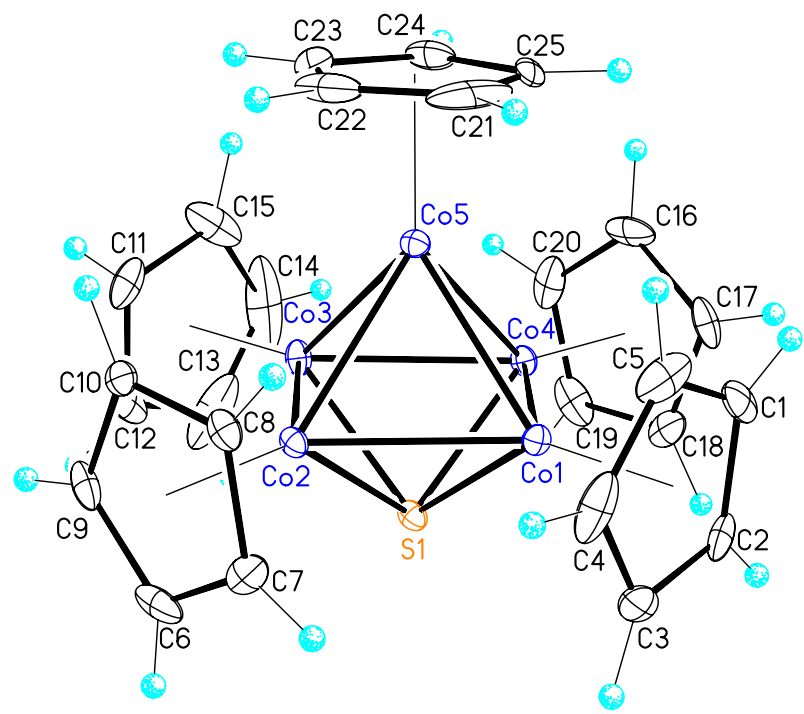

Fig. 1 ORTEP of monoclinic cobalt cluster closo- $\left[\left(\eta^{5}-\mathrm{C}_{5} \mathrm{H}_{5}\right) \mathrm{Co}\right]_{5} \mathrm{~S}(\mathbf{1})$. Ellipsoids are shown at $30 \%$ probability

Table 2 Selected bond length $[\AA]$ and angles $\left[{ }^{\circ}\right]$ for closo- $\left[\left(\eta^{5}-\mathrm{C}_{5} \mathrm{H}_{5}\right) \mathrm{Co}\right]_{5} \mathrm{~S}(\mathbf{1})$

\begin{tabular}{|c|c|c|c|}
\hline $\operatorname{Co}(1)-\operatorname{Co}(2)$ & $2.4334(7)$ & $\operatorname{Co}(2)-S(1)$ & $2.1681(10)$ \\
\hline $\operatorname{Co}(1)-\operatorname{Co}(4)$ & $2.4476(7)$ & $\operatorname{Co}(3)-S(1)$ & $2.1810(11)$ \\
\hline $\operatorname{Co}(2)-\operatorname{Co}(3)$ & $2.4281(7)$ & $\operatorname{Co}(4)-S(1)$ & $2.1665(10)$ \\
\hline $\operatorname{Co}(3)-\operatorname{Co}(4)$ & $2.4514(7)$ & $\mathrm{Co}(5)-\mathrm{S}(1)$ & $3.0200(11)$ \\
\hline $\operatorname{Co}(1)-\operatorname{Co}(5)$ & $2.4014(7)$ & $\operatorname{Cnt}(1)-\operatorname{Co}(1)$ & $1.723(2)$ \\
\hline $\operatorname{Co}(2)-\operatorname{Co}(5)$ & $2.4272(7)$ & $\operatorname{Cnt}(2)-\operatorname{Co}(2)$ & $1.716(2)$ \\
\hline $\operatorname{Co}(3)-\operatorname{Co}(5)$ & $2.4097(7)$ & $\operatorname{Cnt}(3)-\operatorname{Co}(3)$ & $1.725(2)$ \\
\hline $\operatorname{Co}(4)-\operatorname{Co}(5)$ & $2.4338(7)$ & $\operatorname{Cnt}(4)-\operatorname{Co}(4)$ & $1.730(2)$ \\
\hline $\mathrm{Co}(1)-\mathrm{S}(1)$ & $2.1885(10)$ & $\operatorname{Cnt}(5)-\operatorname{Co}(5)$ & $1.760(2)$ \\
\hline
\end{tabular}

86-electron octahedral clusters, $\mathrm{M}_{6}(\mathrm{CO})_{16}, \mathrm{M}=\mathrm{Co}$ [12], Rh [13], and Ir [14] and both isolobal and isostructural analogues of the group- 8 clusters, $\mathrm{M}_{5}(\mathrm{CO}){ }_{15} \mathrm{~S}$, $\mathrm{M}=\mathrm{Ru}$ [15] and Os [16].

The octahedral core of $\mathbf{1}$ is nearly perfect. The cluster-forming angles involving the $\left(\eta^{5}-\mathrm{C}_{5} \mathrm{H}_{5}\right) \mathrm{Co}$ units are all $\pm 1.0^{\circ}$ of 60 and $90^{\circ}$ and the $\mu_{4}$-S cap is very symmetrically placed. The narrow range of Co-S distances is 2.1665(10)$2.1885(10) \AA$. The average is 2.176(1) $\AA$, which is identical to the Co-S average, $2.175(3) \AA$ in $\left[\left(\eta^{5}-\mathrm{C}_{5} \mathrm{H}_{4} \mathrm{Me}\right) \mathrm{Co}\right]_{3}\left(\mu_{3}-\mathrm{S}\right)_{2}$ [17], and very similar to that found in $\left[\left(\eta^{5}-\mathrm{C}_{5} \mathrm{H}_{5}\right) \mathrm{Co}_{3}\left(\mu_{3}-\mathrm{S}\right)_{2}[18,19], 2.168(4) \AA\right.$ A. It is noteworthy that the average Co-S distance in the disulfur octahedral cluster 3, 2.229(1) $\AA$, is somewhat longer, which is in accord with the presence of two additional cluster-forming electrons, compared to $\mathbf{1}$, and the prediction that these additional electrons will occupy a framework antibonding orbital [18]. 
The average Co-Co distance in $\mathbf{1}, 2.429(1) \AA$, is only slightly shorter than in $\mathbf{3}$, 2.438(1) $\AA$. The greater bond length change found for adding two framework electrons on the Co-S bonds, compared to the Co-Co bonds, suggests that the lowest occupied antibonding levels have more $\mathrm{Co}-\mathrm{S}$ than $\mathrm{Co}-\mathrm{Co}$ character, in keeping with the greater electronegativity of $\mathrm{S}$ compared to $\left(\eta^{5}-\mathrm{C}_{5} \mathrm{H}_{5}\right) \mathrm{Co}[13,20]$.

\section{Supplementary Data}

CCDC-710868 contains the crystallographic data in CIF format for cluster $\mathbf{1}$. These data can be obtained free of charge via www.ccdc.cam.ac.uk/conts/retrieving.html (or from the Cambridge Crystallographic Data Centre, 12 Union Road, Cambridge CB2 1EZ, UK; fax: (+44) 1223-336-033; or email: deposit@ccdc.cam.ac.uk).

Acknowledgments Financial support of the National Science Foundation (CHE-0518707; and instrumentation grants CHE-9709183, CHE-0116662, and CHE-07411968) is gratefully acknowledged.

Open Access This article is distributed under the terms of the Creative Commons Attribution Noncommercial License which permits any noncommercial use, distribution, and reproduction in any medium, provided the original author(s) and source are credited.

\section{References}

1. C. E. Housecroft, in T. P. Fehlner (ed.), Inorganometallic Chemistry (Plenum, New York, 1992), pp. 73-169.

2. G. González-Moraga Cluster Chemistry (Springer-Verlag, Berlin, 1993), pp. 177-197.

3. J. M. O’Connor, H. Ji, M. Iranpour, and A. L. Rheingold (1993). J. Am. Chem. Soc. 115, 1586-1588.

4. Wakatsuki, H. Yamazaki, E. Lindner, and A. Bosamle Inorganic Synthesis (Wiley-Interscience, New York, NY, 1989).

5. J. M. O’Connor, H.-L. Ji, and A. L. Rheingold (1993). J. Am. Chem. Soc. 115, 9846-9847.

6. J. M. O'Connor, B. S. Fong, H.-L. Ji, K. Hiibner, and A. L. Rheingold (1995). J. Am Chem. Soc. 117, 8029-8030.

7. J. M. O'Connor, M.-C. Chen, M. Frohn, A. L. Rheingold, and I. A. Guzei (1997). Organometallics 16, 5589-5591.

8. J. M. O'Connor, M.-C. Chen, and A. L. Rheingold (1997). Tetrahedron Lett 38, 5241-5244.

9. R. L. Holland, K. D. Bunker, C. H. Chen, A. G. DiPasquale, A. L. Rheingold, K. K. Baldridge, and J. M. O’Connor (2008). J. Am. Chem. Soc. 130, 10093-10095.

10. D. M. P. Mingos and D. J. Wales Introduction to Cluster Chemistry (Prentice Hall, Englewood Cliffs, NJ, 1990).

11. F. Jiang, X. Lei, Z. Huang, M. Hong, B. Kang, D. Wu, and H. Liu (1990). Chem. Commun. 16551656.

12. V. Albano, P. Chini, and V. Scatturin (1968). Chem. Commun. 163-164.

13. E. R. Corey, L. F. Dahl, and W. Beck (1963). J. Am. Chem. Soc. 85, 1202-1203.

14. L. Garlaschelli, S. Martinengo, P. L. Bellon, F. Demartin, M. Manassero, M. Y. Chiang, C.-Y. Wei, and R. Bau (1984). J. Am. Chem. Soc. 106, 6664-6667.

15. R. D. Adams, J. E. Babin, and M. Tasi (1988). Organometallics 7, 503-513.

16. R. D. Adams, I. T. Horvàth, B. E. Segmüller, and L.-W. Yang (1983). Organometallics 2, 1301-1308.

17. C. R. Pulliam, J. B. Thoden, A. M. Stacy, B. Spencer, M. H. Englert, and L. F. Dahl (1991). J. Am. Chem. Soc. 113, 7398-7410.

18. P. D. Frisch and L. F. Dahl (1972). J. Am. Chem. Soc. 94, 5082-5084.

19. N. Kamijo and T. Watanabé (1979). Acta Crystallogr. B35, 2537-2542.

20. J.-F. Halet, R. Hoffmann, and J.-Y. Saillard (1985). Inorg.Chem. 24, 1695-1700. 